\title{
Studi Eksperimen Pengaruh Variasi Kecepatan Putar Terhadap Temperatur dan Tensile Strength pada Friction Welding dengan Material High-Density Polyethylene
}

\author{
Miftahul Ahzabuddin dan Yusuf Kaelani \\ Departemen Teknik Mesin, Fakultas Teknologi Industri, Institut Teknologi Sepuluh Nopember (ITS) \\ e-mail:y_kaelani@me.its.ac.id
}

\begin{abstract}
Abstrak-Pengelasan gesek atau disebut dengan friction welding adalah sebuah proses pengelasan solid-state dimana penyambungan terjadi oleh panas akibat perputaran permukaan bahan yang akan dilas terhadap permukaan lainnya di bawah pengaruh tekanan aksial (tekanan gesek dan tekanan tempa). Proses pengelasan ini sangat dipengaruhi oleh kecepatan putar, durasi gesekan, tekanan aksial, sifat material dan kondisi permukaan benda kerja. Penelitian ini memvariasikan kecepatan putar sebesar $300 \mathrm{rpm}, 520 \mathrm{rpm}$ dan $750 \mathrm{rpm}$ dalam durasi gesekan 15 detik dengan diberikan tekanan gesek sebesar 37,51 $\mathrm{kgf} / \mathrm{cm}^{2}$ sampai mencapai temperatur tertentu, kemudian diberikan tekanan tempa sebesar $75,02 \mathrm{kgf} / \mathrm{cm}^{2}$. Material yang digunakan yaitu High density Polyethylene-300 (HDPE) Pengujian mekanik yang dilakukan adalah uji tarik dengan membandingkan HDPE yang disambung menggunakan lem perekat. Hasil penelitian ini kekuatan tarik terbaik didapatkan pada kecepatan 520 rpm sebesar 35,21 MPa dengan temperatur interface sebesar $70{ }^{\circ} \mathrm{C}$. Hasil ini lebih baik dibandingkan dengan penyambungan lem. Temperatur pada jarak $7 \mathrm{~mm}$ merupakan daerah transisi antara terpengaruhi panas dengan temperatur lingkungan yang berpengaruh pada upset tertinggi sebesar $6 \mathrm{~mm}$.
\end{abstract}

Kata Kunci-Friction Welding, HDPE, kecepatan Putar, Kekuatan Tarik, Temperatur.

\section{PENDAHULUAN}

$\mathrm{P}$ ADA umumnya benda yang bergerak dan mempunyai kontak dengan benda lainnya, akan terjadi gesekan sehingga menimbulkan keausan. Hal tersebut dapat menyebabkan kerusakan pada komponen ataupun peralatan. Gaya gesek terjadi apabila dua benda bergesekan yaitu permukaan kedua benda bersinggungan pada waktu benda yang satu bergerak terhadap yang lainnya [1]. Namun, dengan adanya gesekan yang menimbulkan panas dapat dimanfaatkan untuk penyambungan dua benda dengan metode friction welding. Metode las gesek (friction welding) adalah metode penyambungan dua buah benda padat yang menghasilkan perpaduan material dengan kekuatan tekan saat benda berputar atau bergerak relatif satu sama lain yang dapat menghasilkan panas pada kedua sisi kontak. Proses pengelasan gesek dilakukan dengan memutar salah satu komponen sementara yang lain dalam kondisi diam. Panas yang ditimbulkan akibat gesekan, mengakibatkan kedua sisi permukaan kontak meleleh. Poros yang berputar dihentikan dan dilakukan

penekanan tempa sebelum sambungan dalam kondisi dingin [2].

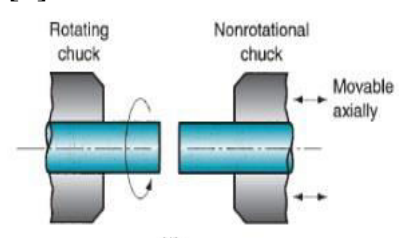

(1)

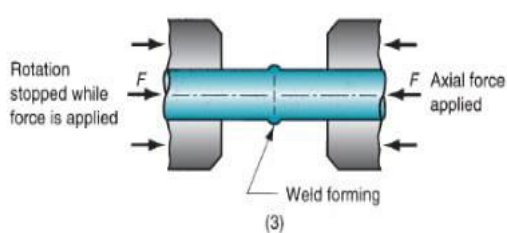

Gambar 1. Proses friction welding

Gesekan yang terjadi akan menimbulkan panas dan menyebabkan keausan. Keausan yang lebih besar terjadi pada bahan yang lebih lunak. Salah satunya pada material polyethylene. Polyethylene merupakan salah satu jenis polimer termoplastik yang sering digunakan pada kehidupan seharihari. Polyethylene (PE) biasanya digunakan sebagai pipa saluran, botol plastik, bahan cetakan, dan handle. Dalam penggunaannya banyak terjadi kontak dengan bahan-bahan kimia sehingga produk harus memiliki resistensi terhadap bahan kimia tersebut. Salah satunya sebagai kajian prosthesis sendi rahang manusia yang menggunakan material komposit Hidroksiapatit (HA) dan Polymethyl Methacrylate (PMMA) dengan Molecular Weight Polyethylene (UHMWPE) [3]. Proses penyambungan PE selain menggunakan lem dan penambahan shock, bisa juga dengan pengelasan gesek (friction welding).

Polimer termoplastik memiliki sifat tidak tahan terhadap panas, apabila dipanaskan maka akan menjadi lunak, didinginkan akan mengeras dan rapuh (brittle), dan berubah menjadi gelas (glassy) jika dibiarkan pada suhu kamar. Proses tersebut dapat terjadi berulang kali, sehingga dapat dibentuk ulang dalam berbagai bentuk cetakan yang berbeda untuk mendapatkan produk polimer baru [4]. Pada pengelasan gesek sangat berpengaruh pada kecepatan putar, durasi gesek, tekanan gesek dan tekanan tempa. Variabel-variabel ini sifatnya saling mempengaruhi dan berdampak pada hasil 
pengelasan. Oleh Karena itu dilakukan penelitian untuk mengkaji panas yang ditimbulkan (temperatur) dan uji tarik.

\section{METODE PENELITIAN}

\section{A. Material}

Dalam penelitian ini, material yang digunakan adalah High Density Polyethylene (HDPE tipe 300) berdiameter $20 \mathrm{~mm}$ dengan panjang $130 \mathrm{~mm}$ seperti pada gambar 2. Proses pembuatan spesimen diantaranya pemotongan material, facing, turning, memperkecil diameter sebesar $12,7 \mathrm{~mm}$ dan radius sebesar $4,5 \mathrm{~mm}$ serta dilakukan penghalusan permukaan penyambungan dengan amplas 1200 grit [5].

\section{B. Penyambungan dengan Friction Welding}

Proses friction welding dilakukan pada spesimen yang telah dibuat dan dihaluskan permukaan agar rata. Spesimen awal mempunyai panjang awal $400 \mathrm{~mm}$ sebanyak 9 pasang. Proses pengelasan menggunakan mesin friction welding sebagai berikut:

1. Pembuatan spesimen sesuai ukuran dengan memotong menggunakan gergaji, meratakan permukaan dengan mesin bubut dan menghaluskan permukaan dengan kertas gosok.

2. Pemasangan benda kerja pada cekam.

3. Pengaturan kecepatan putaran spindle yang digunakan sebesar $(300,520,750) \mathrm{rpm}$.

4. Mesin dihidupkan, tunggu beberapa detik hingga putaran stabil.

5. Pemberian tekanan gesek sebesar $37,51 \mathrm{kgf} / \mathrm{cm}^{2}$.

6. Proses pengelasan dimulai, perhitungan durasi gesek selama 15 detik.

7. Setelah waktu terpenuhi maka motor dimatikan sehingga putaran mengalami perlambatan dan dilakukan pengereman.

8. Pemberian tekanan tempa sebesar $75,02 \mathrm{kgf} / \mathrm{cm}^{2}$.

9. Didiamkan \pm 30 detik.

10. Pelepasan benda kerja pada cekam.

11. Pengecekan hasil lasan.

12. Melakukan pengelasan sebanyak 3 kali pada masingmasing kecepatan putar $(300,520,750) \mathrm{rpm}$.

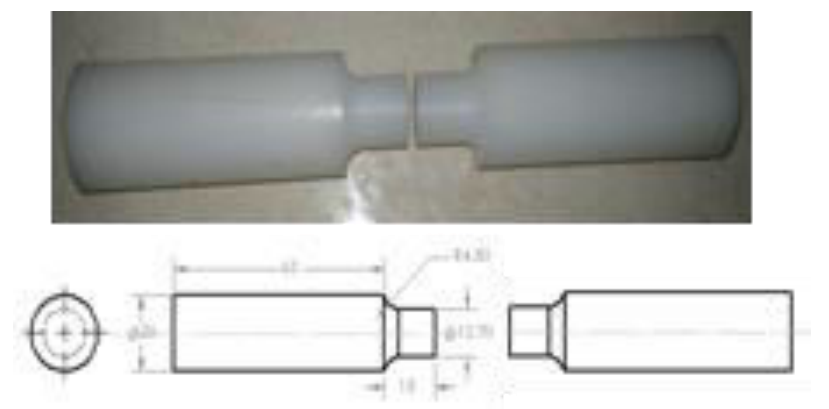

Gambar 2. Spesimen uji.

\section{Penyambungan dengan Pengeleman}

Penyambungan kedua material menggunakan jenis lem epoxy multi fungsi untuk bermacam-macam material. Kekuatan tarik hasil penyambungan dengan lem ini bisa mencapai lebih dari $20 \mathrm{MPa}$. Waktu optimal untuk mencapai hasil sambungan yang baik yaitu lebih dari 3 jam.

\section{Pengambilan Data Temperatur Pengelasan}

Pada saat pengelasan dilakukan pengambilan data temperatur dengan infrared thermograph dan termokopel. Adapun langkah-langkah pengambilan data temperatur friction welding adalah sebagai berikut:

1. Spesimen sudah terpasang di kedua chuck mesin friction welding.

2. Termokopel ditempelkan ujungnya tepat pada permukaan spesimen yang saling bergesekan.

3. infrared thermograph dinyalakan dan ditembakkan pada spesimen HDPE yang tidak berputar dengan jarak $7 \mathrm{~mm}$ dari interface.

Pengambilan data dilakukan saat awal spesimen berputar hingga berhenti dan mengalami penekanan tempa.

\section{E. Pengujian Tarik}

Uji tarik dilakukan dengan membuat spesimen yang akan diuji tarik dibuat menjadi bentuk yang sesuai dengan standar seperti terlihat pada gambar 2. Mesin uji tarik yang digunakan adalah Gotech Universal testing machine dengan kapasitas $2000 \mathrm{kN}$ untuk pengujian setelah proses friction welding. Adapun langkah-langkah pengujian tarik adalah sebagai berikut:

1. Mempersiapkan spesimen.

2. Menghidupkan control power, hydraulic power, dan servo motor.

3. Menentukan data dan dimensi spesimen.

4. Memasang spesimen pada penjepit (chuck).

5. Memberikan pembebanan

6. Setelah patah, spesimen dilepas dari penjepit.

7. Hasil pengujian pada lembar kertas pada roller dan penghitungan manual.

8. Setelah pengujian selesai, semua power dimatikan secara berurutan.

\section{ANALISA DAN PEMBAHASAN}

\section{A. Data Temperatur Percobaan Friction Welding}

Pengambilan data temperatur pada percobaan ini menggunakan termokopel tipe $\mathrm{K}$ tepat pada permukaan yang bergesekan $(\mathrm{x}=0)$ dan menggunakan infrared termometer pada jarak $7 \mathrm{~mm}$ dari permukaan yang bergesekan. Percobaan friction welding yang dilakukan pada spesimen sebanyak 9 pasang dengan parameter variasi kecepatan mendapatkan data seperti yang terlihat pada tabel 1 dan 2 sebagai berikut:

Tabel 1.

Hasil data temperatur percobaan pada interface 


\begin{tabular}{|c|c|c|c|c|c|c|c|c|c|c|c|c|}
\hline \multirow{3}{*}{$\begin{array}{l}\text { Durasi } \\
\text { (detik) }\end{array}$} & \multicolumn{4}{|c|}{$300 \mathrm{rpm}$} & \multicolumn{4}{|c|}{$520 \mathrm{rpm}$} & \multicolumn{4}{|c|}{$750 \mathrm{rpm}$} \\
\hline & \multicolumn{12}{|c|}{ Temperatur $\left({ }^{\circ} \mathrm{C}\right)$} \\
\hline & 1 & 2 & 3 & rata-rata & 1 & 2 & 3 & rata-rata & 1 & 2 & 3 & rata-rata \\
\hline 1 & 30 & 31 & 33 & 31.33 & 40 & 34 & 33 & 35.67 & 33 & 35 & 31 & 33.00 \\
\hline 3 & 41 & 32 & 34 & 35.67 & 44 & 39 & 35 & 39.33 & 36 & 40 & 39 & 38.33 \\
\hline 6 & 50 & 42 & 38 & 43.33 & 48 & 50 & 39 & 45.67 & 50 & 55 & 78 & 61.00 \\
\hline 9 & 57 & 56 & 51 & 54.67 & 52 & 54 & 46 & 50.67 & 74 & 76 & 102 & 84.00 \\
\hline 12 & 66 & 62 & 52 & 60.00 & 57 & 59 & 54 & 56.67 & 91 & 94 & 109 & 98.00 \\
\hline 15 & 75 & 61 & 57 & 64.33 & 70 & 71 & 69 & 70.00 & 94 & 95 & 109 & 99.33 \\
\hline 18 & 76 & 61 & 69 & 68.67 & 75 & 74 & 72 & 73.67 & 95 & 90 & 108 & 97.67 \\
\hline 21 & 79 & 75 & 78 & 77.33 & 79 & 77 & 78 & 78.00 & 92 & 87 & 104 & 94.33 \\
\hline 25 & 80 & 81 & 79 & 80.00 & 81 & 80 & 81 & 80.67 & 91 & 85 & 100 & 92.00 \\
\hline
\end{tabular}

Tabel 2.

Hasil data temperatur percobaan pada jarak $7 \mathrm{~mm}$

\begin{tabular}{|c|c|c|c|c|c|c|c|c|c|c|c|c|}
\hline \multirow{2}{*}{ Durasi } & \multicolumn{9}{|c|}{$300 \mathrm{rpm}$} & \multicolumn{7}{|c|}{$520 \mathrm{rpm}$} & \multicolumn{5}{|c|}{$750 \mathrm{rpm}$} \\
\cline { 2 - 17 } & \multicolumn{10}{|c|}{ Temperatur $\left({ }^{\circ} \mathrm{C}\right)$} \\
\hline (detik) & 1 & 2 & 3 & rata-rata & 1 & 2 & 3 & $\begin{array}{c}\text { rata- } \\
\text { rata }\end{array}$ & 1 & 2 & 3 & $\begin{array}{c}\text { rata- } \\
\text { rata }\end{array}$ \\
\hline 1 & 32.6 & 33.1 & 33 & 32.9 & 32.2 & 33.2 & 33.2 & 32.9 & 33.1 & 33.3 & 33 & 33.1 \\
\hline 3 & 32.6 & 33.2 & 33.4 & 33.1 & 32.3 & 33.9 & 33.7 & 33.3 & 33.3 & 33.4 & 33.3 & 33.3 \\
\hline 6 & 32.7 & 33.3 & 33.5 & 33.2 & 32.4 & 34.5 & 33.7 & 33.5 & 33.6 & 34.2 & 33.5 & 33.8 \\
\hline 9 & 32.9 & 33.5 & 33.7 & 33.4 & 32.4 & 35.2 & 34.2 & 33.9 & 33.8 & 34.3 & 34.3 & 34.1 \\
\hline 12 & 33 & 33.9 & 34.1 & 33.7 & 32.6 & 35.2 & 34.3 & 34.0 & 34.2 & 35 & 34.3 & 34.5 \\
\hline 15 & 33.1 & 34 & 34.4 & 33.8 & 32.7 & 35.5 & 34.7 & 34.3 & 34.4 & 36 & 35 & 35.1 \\
\hline 18 & 33.3 & 34.1 & 34.4 & 33.9 & 32.9 & 34.5 & 35.2 & 34.2 & 34.2 & 36.2 & 35.2 & 35.2 \\
\hline 21 & 33.3 & 34.3 & 34.6 & 34.1 & 33.2 & 34.2 & 34.8 & 34.1 & 34.2 & 35.7 & 34.8 & 34.9 \\
\hline 25 & 33.5 & 34.3 & 34.5 & 34.1 & 33.2 & 34.2 & 34.5 & 34.0 & 34 & 35.5 & 34.4 & 34.6 \\
\hline
\end{tabular}

Tabel 3.

Hasil data uji tarik

\begin{tabular}{|c|c|c|c|c|}
\hline No & $\begin{array}{c}\text { Kecepatan } \\
\text { Putar (rpm) }\end{array}$ & $\begin{array}{l}\text { UTS } \\
(\mathrm{MPa})\end{array}$ & $\begin{array}{c}\text { UTS } \\
\text { rata-rata } \\
(\mathrm{MPa})\end{array}$ & $\begin{array}{l}\text { Daerah } \\
\text { Patahan }\end{array}$ \\
\hline 1 & \multirow{3}{*}{300} & 31.97 & \multirow{3}{*}{32.69} & interface \\
\hline 2 & & 33.34 & & interface \\
\hline 3 & & 32.75 & & interface \\
\hline 1 & \multirow{3}{*}{520} & 32.56 & \multirow{3}{*}{33.83} & HAZ \\
\hline 2 & & 33.73 & & interface \\
\hline 3 & & 35.21 & & HAZ \\
\hline 1 & \multirow{3}{*}{750} & 32.75 & \multirow{3}{*}{33.34} & Interface \\
\hline 2 & & 33.73 & & HAZ \\
\hline 3 & & 33.54 & & interface \\
\hline 1 & \multirow{3}{*}{ Lem } & 33.34 & \multirow{3}{*}{32.92} & interface \\
\hline 2 & & 32.75 & & interface \\
\hline 3 & & 32.66 & & interface \\
\hline
\end{tabular}

Tabel 4.

Hasil data upset

\begin{tabular}{|c|c|c|c|}
\hline Kecepatan (rpm) & Spesimen & Upset (mm) & $\begin{array}{c}\text { rata-rata } \\
(\mathbf{m m})\end{array}$ \\
\hline \multirow{3}{*}{300} & 1 & 3 & \multirow{3}{*}{3.33} \\
\hline & 2 & 3 & \\
\hline & 3 & 4 & \\
\hline \multirow{3}{*}{520} & 1 & 3 & \multirow{3}{*}{3.67} \\
\hline & 2 & 4 & \\
\hline & 3 & 4 & \\
\hline \multirow{3}{*}{750} & 1 & 4 & \multirow{3}{*}{5.00} \\
\hline & 2 & 6 & \\
\hline & 3 & 5 & \\
\hline
\end{tabular}

\section{B. Data Pengujian Tarik Friction Welding}

Pengujian tarik dilakukan sebanyak 9 pasang spesimen dengan parameter variasi kecepatan dan 3 pasang spesimen yang disambung menggunakan lem. Kekuatan tarik pada material HDPE tipe 300 sebesar 42,56 MPa. Dari pengujian tarik didapatkan kekuatan tarik (Ultimate Tensile Strength) hasil penyambungan, seperti yang terlihat pada tabel 3 .

\section{Data Upset Penyambungan Friction Welding}

Hasil penyambungan dengan friction welding menghasilkan upset akibat variasi kecepatan putar. Pengurangan panjang (upset) yang terjadi dapat ditunjukkan pada tabel 4.

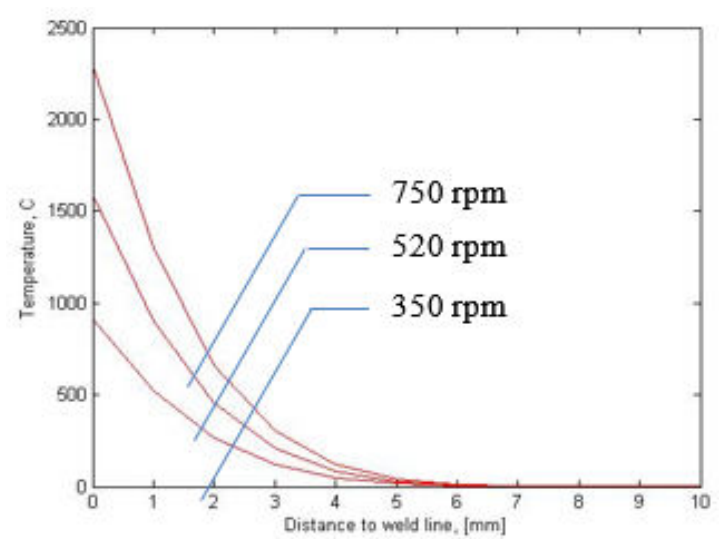

Gambar 3. Grafik temperatur pada waktu 15 detik.

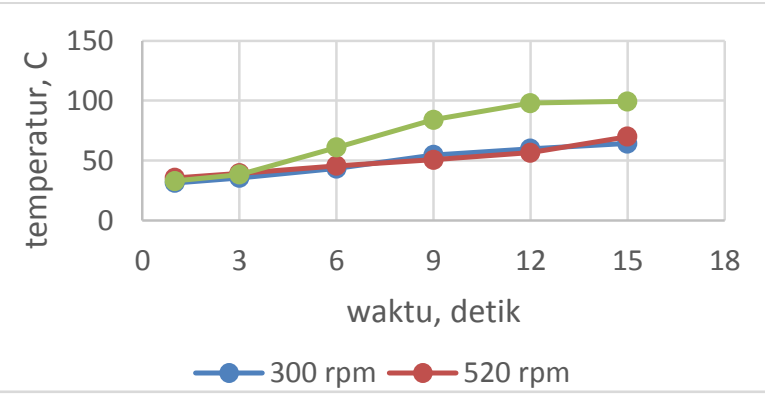

Gambar. 4. Data temperatur percobaan pada interface.

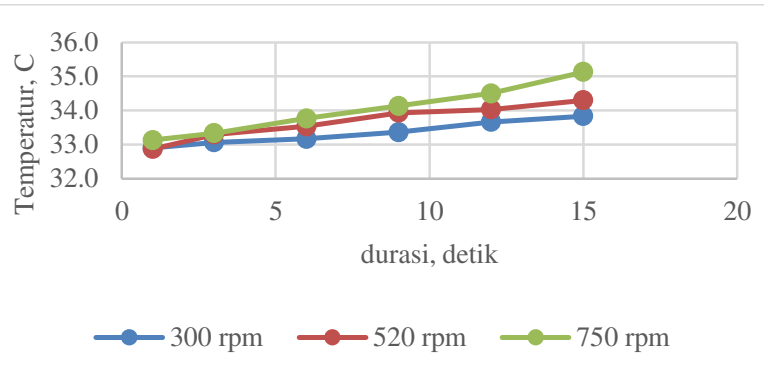

Gambar 5. Data temperatur percobaan pada jarak $7 \mathrm{~mm}$.

\section{Analisa Numerik Temperatur Proses Friction Welding}

Panas yang ditimbulkan akibat gesekan menggunakan persamaan (1) [6], dan temperatur dihitung berdasarkan persamaan (2) dimana $\dot{q}$ adalah heat flux dalam satuan $\mathrm{W} / \mathrm{mm}^{2}$. Koefisien gesek material $(\mu)$, kecepatan putar $(\omega)$ dalam rad/s, tekanan gesek $(\mathrm{P})$ dalam $\mathrm{N} / \mathrm{mm}^{2}$ dan radius permukaan gesek (r) dalam mm. Fungsi temperatur terhadap jarak dan waktu, dimana $T_{0}$ merupakan temperatur awal, konduktivitas material $(\mathrm{K})$ dalam $\mathrm{W} / \mathrm{mm} . \mathrm{K}$, dimana $\alpha=$ $\mathrm{K} / \rho . \mathrm{Cp}$ dalam $\mathrm{mm}^{2} / \mathrm{s}$. Massa jenis material $(\rho)$ dan spesifik kapasitas panas $\left(\mathrm{C}_{\mathrm{p}}\right)$ 


$$
\begin{aligned}
& \dot{\mathrm{q}}=\mu . \omega . \text {. .r } \\
& T\{x, t\}=T_{0}+\frac{\mathrm{q}}{K}\left(2 \sqrt{\frac{\alpha \mathrm{t}}{\pi}} \exp \left\{\frac{-x^{2}}{4 \alpha \mathrm{t}}\right\}-\operatorname{xerfc}\left\{\frac{x^{2}}{\sqrt{4 \alpha \mathrm{t}}}\right\}\right)
\end{aligned}
$$

Dari hasil analisa perhitungan menggunakan persamaan fourier [7]. Perhitungan temperatur menggunakan MATLAB menunjukkan hasil berupa grafik suhu pada spesimen selama tahap pemanasan seperti pada gambar 3, bahwa pada durasi 15 detik dengan kecepatan 300, 520, dan 750 rpm tepat pada permukaan yang bergesekan sudah mencapai temperatur yang melebihi temperatur leleh HDPE sebesar $130{ }^{\circ} \mathrm{C}$.

Pada kecepatan $300 \mathrm{rpm}$ menghasilkan heat flux sebesar $0,2212 \mathrm{~W} / \mathrm{mm}^{2}$ dan untuk mencapai temperatur leleh hanya membutuhkan durasi 0,3 detik. Hal ini cukup sesuai pendekatan secara teori karena umumnya bahwa suhu tertinggi yang dicapai pada interface friction welding dalam waktu yang singkat. Wang dan Nagappan mengakui bahwa temperatur pada pengelasan inersia untuk mencapai temperatur puncaknya hanya dalam durasi 0,2 detik. Soucail juga menyatakan bahwa suhu $1280{ }^{\circ} \mathrm{C}$ dicapai dalam waktu kurang dari 1 detik selama pengelasan inersia [7].

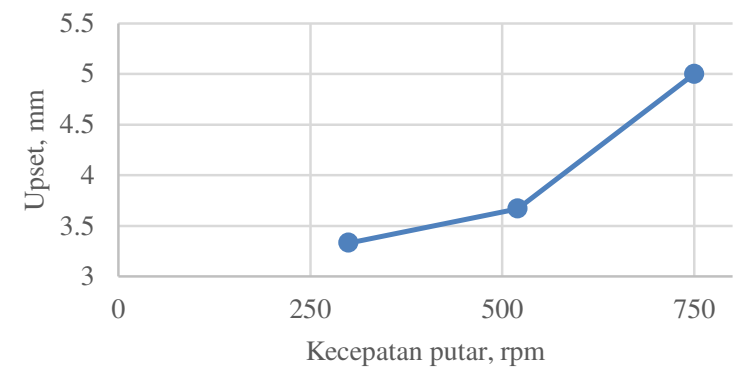

Gambar 6. Grafik upset dengan variasi kecepatan putar

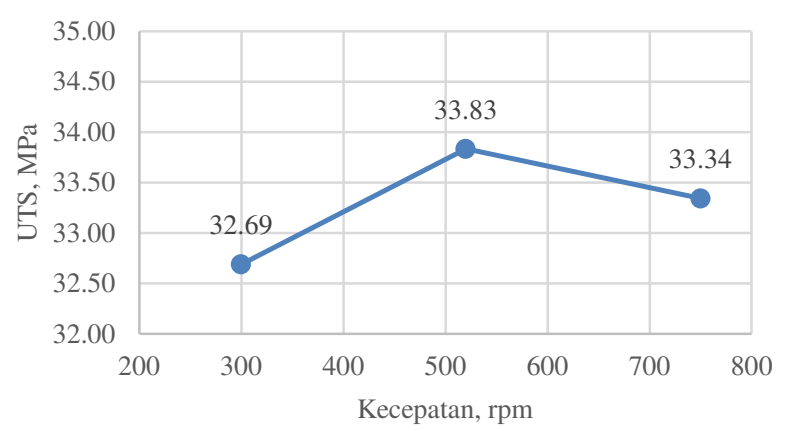

Gambar 7. Grafik pengaruh kecepatan putar terhadap UTS rata-rata.

Pada kondisi ini, heat flux yang dihasilkan diasumsikan kondisi konstan pada seluruh area permukaan spesimen yang bergesekan. Model persamaan yang digunakan yaitu semiinfinite one-dimensional panas secara konduksi, tanpa memperhatikan distribusi panas pada koordinat lain dan konveksi. Material High Density Polyethylene merupakan salah satu jenis plastik. Dimana material ini bersifat tidak mudah menyerap panas (isolator). Pada jarak $7 \mathrm{~mm}$ dari permukaan spesimen yang saling bergesekan menunjukkan transisi antara temperatur yang terpengaruhi panas dengan temperatur material. Baik itu pada kecepatan putar 300, 520, dan $750 \mathrm{rpm}$ pada jarak $7 \mathrm{~mm}$ tidak terpengaruh dengan panas yang ditimbulkan.

\section{E. Analisa Data Temperatur Percobaan Friction Welding}

Dari tabel 1 hasil data temperatur percobaan pada interface diatas, selanjutnya dapat diketahui hubungan antara durasi gesekan dengan temperatur yang dihasilkan pada setiap kecepatan putar yang divariasikan. Hubungan ini dapat dibuat suatu grafik seperti pada gambar 4 sebagai berikut:

Pada grafik tersebut menunjukkan bahwa pada kecepatan 300, 520 dan $750 \mathrm{rpm}$ semakin lamanya durasi gesekan, maka temperatur pada interface akan semakin naik sampai pada waktu 15 detik. Pada kecepatan 300 rpm, temperatur gesekan tertinggi hanya pada $64,33{ }^{\circ} \mathrm{C}$. Pada kecepatan $520 \mathrm{rpm}$, menunjukkan temperatur sebesar $70{ }^{\circ} \mathrm{C}$. Sedangkan pada 750 rpm, mencapai pada temperatur $99,33{ }^{\circ} \mathrm{C}$. Setelah kondisi gesekan berakhir, dilanjutkan dengan tekanan tempa.

Hasil pengambilan data percobaan pada interface yang saling bergesekan ini berbeda jauh dengan perumusan analisa numerik pada grafik 2 . Hal ini diakibatkan oleh pengukuran temperatur menggunakan termokopel yang hanya dapat membaca temperatur gesekan pada permukaan luar saja. Selain itu, berbagai faktor perpindahan panas juga mempengaruhi. Penekanan tempa setelah fase gesekan dilakukan untuk mencegah penurunan temperatur selama proses penyambungan. Namun pada kecepatan putar $750 \mathrm{rpm}$ dengan tekanan tempa sebesar $37,51 \mathrm{kgf} / \mathrm{cm}^{2}$ masih belum cukup mampu mempertahankan temperatur pada $99.33^{\circ} \mathrm{C}$.

Pada gambar 5 menunjukkan grafik hubungan durasi gesekan dengan temperatur yang dihasilkan selama fase gesekan. Semakin lama durasi gesekan maka akan terjadi kenaikan temperatur. Pada hasil pengambilan data temperatur pada jarak $7 \mathrm{~mm}$ dari interface ini hanya berkisar mulai dari $33{ }^{\circ} \mathrm{C}$ sampai $35,7{ }^{\circ} \mathrm{C}$. Hal ini menunjukkan pada jarak tersebut merupakan wilayah transisi dari pengaruh panas akibat heat flux yang ditimbulkan di interface dengan temperatur spesimen.

\section{F. Analisa Data Upset}

Dari gambar 6 dapat dilihat pada variasi kecepatan putar bahwa upset memiliki tren naik seiring bertambahnya kecepatan putar. Nilai upset rata-rata tertinggi pada kecepatan putar $750 \mathrm{rpm}$ sebesar $5 \mathrm{~mm}$ dan minimum pada kecepatan putar $300 \mathrm{rpm}$ bernilai upset rata-rata $3,33 \mathrm{~mm}$.

Upsetting (pemendekan) diakibatkan terjadinya deformasi plastik yang terjadi pada permukaan kedua spesimen. Pada saat interface sudah dalam kondisi lumer, timbul adanya pergerakan volume yang akan membentuk flash serta geramgeram yang terlebih dahulu cepat mengalami pendinginan. Jika temperatur tinggi pada interface maka upset yang terjadi semakin besar serta rongga-rongga pada sambungan akan semakin hilang, dengan demikian maka kekuatan tarik akan semakin besar. Namun pada sebaliknya jika upset yang terjadi kecil, berarti daerah yang lumer akibat temperatur yang rendah sehingga tidak dapat menghilangkan udara yang terperangkap pada sambungan yang menyebabkan kekuatan tariknya 
menurun.

\section{G. Analisa Data Pengujian Tarik}

Dari data pengujian tarik pada tabel 3 dibuat grafik hubungan antara kecepatan putar dengan kekuatan tarik UTS (Ultimate Tensile Strength) yang dapat dilihat pada gambar 7 .

Berdasarkan gambar 7 dapat dilihat grafik dengan variasi kecepatan sebesar 300, 520 dan 750 rpm terlihat bahwa kecepatan putar mempengaruhi kekuatan tarik. Kekuatan tarik rata-rata tertinggi sebesar 33,83 $\mathrm{MPa}$ dilakukan penyambungan friction welding pada kecepatan $520 \mathrm{rpm}$.

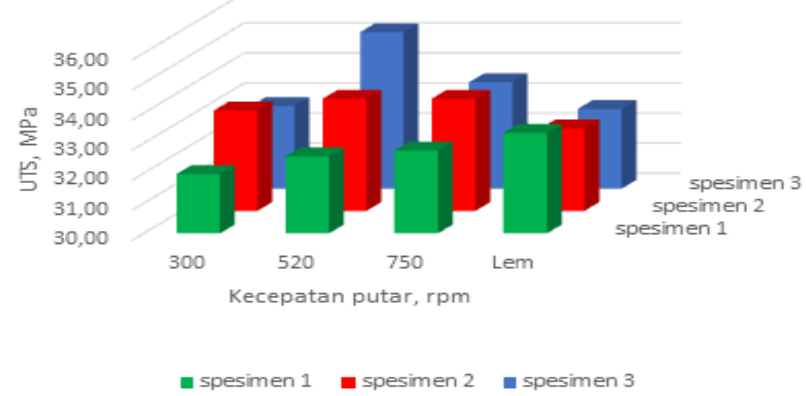

Gambar 8. Diagram pengaruh kecepatan putar terhadap UTS masing specimen.

Panas yang ditimbulkan akibat gesekan pada temperatur tinggi juga menyebabkan ikatan-ikatan unsur pembentuknya berubah menjadi silang dan diikuti pemutusan ikatan secara acak. Sehingga ikatan pada sambungan tidak lagi sama dengan ikatan material pembentuknya berupa ikatan yang lurus dan rapat.

Pada gambar 8 menunjukkan diagram perbedaan variasi kecepatan dan penyambungan menggunakan lem berpengaruh pada Ultimate Tensile Strength (UTS). Penyambungan dengan friction welding menghasilkan kekuatan tarik lebih besar daripada menggunakan lem. Namun, pada kecepatan putar 300 rpm kekuatan tariknya masih sedikit dibawah penyambungan lem. Hal ini dikarenakan lem mempunyai spesifikasi kekuatan tarik minimal $20 \mathrm{MPa}$. Penyambungan menggunakan lem saat dilakukan pengujian tarik, patah pada sambungan dan bekas lemnya juga terlepas dari spesimen.

Hasil pengujian tarik pada masing-masing spesimen, dengan kecepatan $520 \mathrm{rpm}$ pada spesimen 3 menunjukkan bahwa menghasilkan kekuatan tarik terbesar. Melihat data temperaturnya pada saat awal fase gesekan, menunjukkan peningkatan temperatur yang lebih cepat dari spesimen lainnya. Sehingga panas yang ditimbulkan dapat menyebar merata dengan baik. Flash yang dihasilkan tidak terlalu besar serta tidak bergranula terlihat pada gambar 8. Selain itu terlihat pada upset yang terjadi tidak terlalu besar yang berarti pada kecepatan putar ini cukup untuk menghilangkan void pada sambungan.

Panas yang dihasilkan akibat gesekan dengan kecepatan putaran spesimen menyebabkan molekul-molekul seolah akan teraduk secara acak pada interface. Pemberian tekanan gesek untuk menghasilkan panas serta adanya tekanan tempa yang sesuai akan memperlambat pendinginannya sehingga kesempatan molekul dapat membuat ikatan yang lebih kuat
Namun, ketika dilakukan pengujian tarik spesimen patah pada daerah permukaan penempaan. Hal ini dikarenakan kecepatan putar yang dilakukan belum bisa mencapai temperatur tempa. Sehingga ketika diberikan tekanan tempa, maka tekanan tersebut belum mampu membuat penyambungan yang baik. Selain itu, terjadi penurunan kekuatan tarik pada kecepatan putar $750 \mathrm{rpm}$. Karena tekanan tempa yang seharusnya untuk menahan dari penurunan temperatur, namun tekanan tempa sebesar $37,51 \mathrm{kgf} / \mathrm{cm}^{2}$ tidak mampu menahan pada temperatur $99,33{ }^{\circ} \mathrm{C}$.

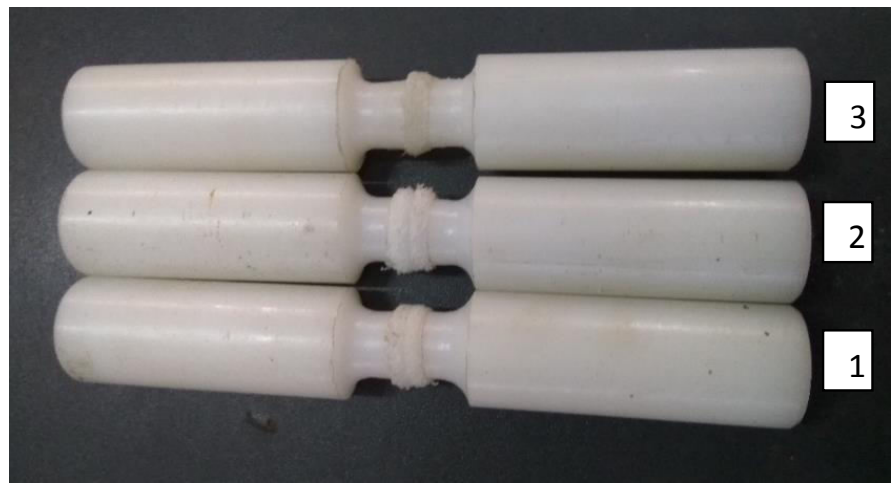

Gambar 8. Hasil penyambungan friction welding pada $520 \mathrm{rpm}$.

akan lebih lama sehigga sambungan lebih kuat. Dengan demikian, kekuatan tariknya pada sambungan akan semakin baik.

\section{KESIMPULAN}

Kesimpulan yang didapatkan dari penelitian setelah proses pengambilan data dan analisa adalah sebagai berikut:

1. Pengaruh variasi kecepatan putar terhadap temperatur dan kekuatan tarik pada material High Density Polyethylene (HDPE):

a. Temperatur $70^{\circ} \mathrm{C}$ merupakan temperatur yang baik untuk penyambungan dengan kecepatan putar 520 rpm. Karena semakin besar temperatur pada interface dan penahanan temperatur yang baik saat pendinginan maka kekuatan tariknya semakin tinggi.

b. Upset terbesar terjadi pada kecepatan putar $750 \mathrm{rpm}$ sejauh $6 \mathrm{~mm}$ karena pada jarak $7 \mathrm{~mm}$ dari interface menghasilkan temperatur yang tidak jauh dari temperatur lingkungan $(33-35,7){ }^{\circ} \mathrm{C}$.

2. Kecepatan putar yang menghasilkan kekuatan tarik tertinggi $(35,21 \mathrm{MPa})$ yaitu pada $520 \mathrm{rpm}$ dengan panas yang dihasilkan (heat flux) $0,37 \mathrm{~W} / \mathrm{mm}^{2}$.

\section{DAFTAR PUSTAKA}

[1] W. Sears and M. . Zemansky, Fisika untuk Universita. Bandung: Bina Cipta, 2001.

[2] W. Li, A. Vairis, and R. . Ward, "Advances in Friction Welding," Mater. Sci. Eng., 2014.

[3] R. Z. Asdi and Y. Kaelani, "Kajian Tribologi Gesekan Antara Material Komposit Hidroksiapatit (HA) + Polymethyl Methacrylate (PMMA) dengan Ultra High Mleculr Weight Polyethylene (UHMWPE) sebagai Prosthesis Sendi Rahang (TMJ) pada Manusia," J. Tek. POMITS, vol. 2, no. 3, 2013.

[4] F. . Firdaus, "Dasar-dasar Ilmu Polimer," Jakarta, 2012.

[5] C. Lin, L. C. Wu, and Y. . Chen, "Friction Welding of Similar Materials: 
Polypropylene, High-Density Polyethylene, and Nylon-6," Taipei Republic of China, 2003.

[6] A. CAN, "Modelling of Friction Welding," in International Scientific Conference, 2010.
[7] L. Yang, Modelling of The Inertia Welding of Inconel 718. Birmingham: University of Birmingham. 